\title{
Development of O-antigen gene cluster-specific PCRs for rapid typing six epidemic serogroups of Leptospira in China
}

\author{
Cheng-Song Cai ${ }^{1 \dagger}$, Yong-Zhang Zhu ${ }^{1 \dagger}$, Yi Zhong ${ }^{2,3}$, Xiao-Fang Xin ${ }^{4}$, Xiu-Gao Jiang ${ }^{5}$, Xiao-Li Lou ${ }^{1}$, Ping He ${ }^{1}$, \\ Jin-Hong Qin ${ }^{1}$, Guo-Ping Zhao ${ }^{2,3,6}$, Sheng-Yue Wang ${ }^{6^{*}}$, Xiao-Kui Guo ${ }^{1 *}$
}

\begin{abstract}
Background: Leptospira is the causative agent of leptospirosis. The O-antigen is the distal part of the lipopolysaccharide, which is a key component of outer membrane of Gram-negative bacteria and confers serological specificity. The epidemiology and clinical characteristics of leptospirosis are relative to the serology based taxonomic unit. Identification of Leptospira strains by serotyping is laborious and has several drawbacks.

Results: In this study, the O-antigen gene clusters of four epidemic Leptospira serogroups (serogroup Canicola, Autumnalis, Grippotyphosa and Hebdomadis) in China were sequenced and all genes were predicted in silico. Adding published sequences of two serogroups, Icterohaemorrhagiae (strain Lai and Fiocruz L1-130) and Sejroe (strain JB197 and L550), we identified six O-antigen-specific genes for six epidemic serogroups in China. PCR assays using these genes were developed and tested on 75 reference strains and 40 clinical isolates.

Conclusion: The results show that the PCR-based assays can be reliable and alternative means for rapid typing of these six serogroups of Leptospira.
\end{abstract}

\section{Background}

Leptospira, a slender and flexuous spirochaete with tight coils, contribute to Leptospirosis [1]. The Leptospira genus has been divided into 20 species based on DNADNA hybridization studies. Pathogenic species include L. interrogans, L. kirschneri, L. noguchii, L. borgpetersenii, L. weilii, L. santarosai, L. alexanderi and L. alstonii [2-6]. Leptospira can also be classified into about 250 serovars based on the lipopolysaccharide (LPS) structure. Antigenically related serovars have been grouped into at least 24 serogroups [4,7].

Leptospirosis exists widely in both temperate and tropical climates and has become a serious public health threat in both developed and developing countries. Human infection results from exposure to the urine of infected animals,

\footnotetext{
* Correspondence: wangsy@shgc.sh.cn; xkguo@shsmu.edu.cn

† Contributed equally

${ }^{1}$ Department of Medical Microbiology and Parasitology, Institutes of Medical Sciences, Shanghai Jiao Tong University School of Medicine, Shanghai 200025, China

${ }^{6}$ Shanghai-MOST Key Laboratory of Health and Disease Genomics, Chinese National Human Genome Center at Shanghai, Shanghai, China
}

either directly or via contaminated soil or water[1,8]. The clinical manifestations of human leptospirosis are highly variable, ranging from mild flu-like symptoms to severe forms of infection with jaundice, pulmonary hemorrhage, multiple organ failure (mainly kidney and liver) and even death [1]. Different clinical characteristics and maintenance hosts are usually associated with certain serovars $[1,8-10]$. Therefore, the serology based taxonomic unit is essential for epidemiology studies, diagnosis and prevention strategies. However, Leptospira serotyping is performed by microscopic agglutination test (MAT) using antisera raised in rabbits against the corresponding standard references strains. This typing method is laborious and time consuming [11].

Chemical, immunochemical and ultrastructural data on LPS show that the epitope for serovar specificity is the $\mathrm{O}$-antigen $[1,12]$. Recently, the $\mathrm{O}$-antigen gene cluster of Gram-negative bacteria has been intensively studied. These genes encode proteins involved in the biosynthesis of the $\mathrm{O}$-antigen and can be divided into three groups [13]. They are nucleotide sugars precursors' biosynthesis genes, glycosyltransferase genes and the $\mathrm{O}$-antigen

\section{() Biomed Central}

(c) 2010 Cai et al; licensee BioMed Central Ltd. This is an Open Access article distributed under the terms of the Creative Commons Attribution License (http://creativecommons.org/licenses/by/2.0), which permits unrestricted use, distribution, and reproduction in any medium, provided the original work is properly cited. 
processing genes. These genes are generally found on the chromosome as an $\mathrm{O}$-antigen gene ( $\mathrm{rfb}$ ) cluster. O-genotyping has been used successfully in several bacteria genus, such as E. coli [14], S. enterica [15], S. boydii [16], and $Y$. pseudotuberculosis [17]. Target genes of these kinds of methods are mainly the second and the third group genes that encode glycosyltransferase and $\mathrm{O}$-antigen processing proteins.

DNA-based typing methods, including variablenumber tandem-repeat (VNTR) typing [18-20], insertion-sequence (IS)-based typing [21,22], pulsed-filed gel electrophoresis (PFGE) $[23,24]$, restriction fragment length polymorphism[25,26] and randomly amplified polymorphic DNA [27] have also been employed for the discrimination of serogroups of Leptospira. Compared with O-genotyping method, the results of these methods are not easy to analyze. Lacking of sequences of $\mathrm{O}$-antigen gene clusters from various serogroups, this kind of O-genotyping has not been developed in Leptospira, however.

It has been confirmed that genetic variation in the $\mathrm{O}$-antigen gene cluster underlies the structural variation in the O-antigen $[28,29]$. It has been demonstrated that $\mathrm{O}$-antigen gene clusters of representative strains from different serogroups of Leptospira were not conservative, especially in the 5'-proximal end [30]. In this research, we sequenced the $\mathrm{O}$-antigen gene cluster of four representative strains belonging to more epidemic serogroups (Canicola, Autumnalis, Grippotyphosa and Hebdomadis) in China [31]. Analyzing the $\mathrm{O}$-antigen gene clusters of 8 sequenced strains (Lai, Fiocruz L1-130, JB197, L550, Gui44, Lin4, Lin6, and C401), we developed simple and practical PCR assays for six epidemic serogroups in China [32] that target serogroup-specific genes and employed to identify strains isolated from clinical samples.

\section{Results and Discussion \\ MAT}

All strains, including 75 reference strains and 40 isolated strains, were tested by MAT with standard rabbit serum. The results are shown in additional file 1 Table S1 and additional file 2 Table S2. The serology results for all reference strains are consistent with those of the National Institute for the Control of Pharmaceutical and Biological Products. Of the 40 isolated strains, 7 strains belong to serogroup Icterohaemorrhagiae, 5 strains belong to serogroup Autumnalis, 11 strains belong to serogroup Grippotyphosa, 1 strain belongs to serogroup Hebdomadis and 5 strains belong to serogroup Sejroe. 5 isolated strains were validated by MAT as Serogroup Ballum, Australis, Javanica and Sarmin, respectively. Six strains were unable to be classified. None of strains belong to serogroup Canicola.

\section{Development of PCR-Based Assays}

We assigned functions of all ORFs by comparing homology genes. Most of predicted proteins are shown to be related to $\mathrm{O}$-antigen biosynthesis except for some hypothetical proteins (see additional file 3 Table S3-6).

For typing bacteria, several different approaches have been used in Leptospira. Serological typing is based on strain to strain differences in the structure of lipopolysaccharide, mainly in the structure of the $\mathrm{O}$-antigen. Recently, PCR-based typing methods targeting specific genes were employed for dicrimination certain serogroups of several bacteria [14-17]. These targeted genes are mainly those encoding glycosyltransferase and enzymes involved in O-antigen assembly. Among them, two highly specific genes: $w z x$ (encode O-unit flippase) and $w z y$ (encode $\mathrm{O}$-antigen polymerase), are O-genotyping targets, usually. Previous analysis of the $\mathrm{O}$-antigen of Leptospira showed that the biosynthesis of LPS in Leptospira is a Wzy-dependent pathway [12,33]. In conjunction with published data [34], our comparison of the $\mathrm{O}$-antigen clusters in all 8 strains shows that the Wzy protein has a high identity among the different serogroups. Similarly, Wzx shows high similarity across other serogroups (data not shown). So we discarded these two genes as PCR assays targets.

To identify highly specific genes for PCR typing, we analyzed all predicted ORFs by the BLAST program. First, we selected genes that exhibit less than $70 \%$ amino acid similarity with their counterpart genes. Second, we compared these selected genes with draft data generated by 454 sequencing and discarded genes with more than $70 \%$ nucleotide similarity to any sequence in the draft data. In silico analysis of sequence of O-antigen clusters in 8 representative strains (Gui44, Lin4, Lin6, C401, JB197, L550, Fiocruz L1-130 and Lai) showed that several glycosyltransferase genes and sugar synthesis genes may be serogroup-specific. Primer pairs were designed to target these genes and PCR were performed.

Analyzing the PCR products, we excluded primer pairs that could generate false-positive results in strains belonging to other serogroups and selected primer pairs that could discriminate as many strains belonging to the serogroups to be tested as possible. The primer pairs listed in Table 1 were our final selections. As shown in Fig. 1, DNA from strains belonging to the corresponding serogroups were able to produce PCR products of the expected size, but no PCR products were obtained from strains belonging to all other serogroups. The results of 75 reference strains are listed in additional file 1 Table S1. We also tested the specificity of six primer pairs using 40 clinically isolated strains; the results are listed in additional file 2 Table S2. All strains belonging to the six serogroups gave PCR products of the expected size with the exception of four reference strains (M49, 
Table 1 PCR primers targeting the specific genes

\begin{tabular}{|c|c|c|c|c|}
\hline Serogroup & Target gene & Primer pairs $\left(5^{\prime} \bullet 3^{\prime}\right)$ & $\begin{array}{c}\text { Annealing } \\
\text { temperature }\left({ }^{\circ} \mathrm{C}\right)\end{array}$ & Amplicon size(bp) \\
\hline \multirow[t]{2}{*}{ Autumnalis } & hypothetical protein & aut-F: TTT TGA TGG GCA TAC TGA & 56 & 298 \\
\hline & & aut-R: TAT GCC CTA AGT GAG TTG C & & \\
\hline \multirow[t]{2}{*}{ Canicola } & dTDP-4-dehydrorhamnose reductase & can-F: CAA AGG TGA TTC ACA AGG & 60 & 341 \\
\hline & & can-R: TCA GTG CAT TAG CCG TAT & & \\
\hline \multirow[t]{2}{*}{ Grippotyphosa } & glycosyltransferase & gri-F: AGA GCC GGA GGA CAG TAA & 63 & 352 \\
\hline & & gri-R: CGA TGG GAA ACC AAG GAT & & \\
\hline \multirow[t]{2}{*}{ Hebdomadis } & carbamoyl transferase & heb-F: GAT TTG ATA AGG CGA AGA & 56 & 656 \\
\hline & & heb-R: AAG CTC CAA TAC ATA AGG AC & & \\
\hline \multirow[t]{2}{*}{ Icterohaemorrhagiae } & glycosyltransferase & ict-F: TाT CAT ACG TTG CGC TTA C & 57 & 590 \\
\hline & & ict-R: ATA AAG TCC AGC ATC ATC CA & & \\
\hline \multirow[t]{2}{*}{ Sejroe } & dehydrogenase & sej-F: CGA CCG AGA TTG ACT ATG TT & 60 & 319 \\
\hline & & sej-R: GAA AGC AGC ATA AGT CCC & & \\
\hline
\end{tabular}

H18, 34 and A81) belonging to the serogroup Sejroe. We speculate that the $\mathrm{O}$-antigen gene clusters of these strains have been undertaken a process of recombination, where target genes may lose through recombination events. Since a few sequences of O-antigen gene clusters from Leptospira are available, only six serogroups of strains have been discriminated so far. There are also six strains cannot be discriminated by both MAT and O-genotyping in clinical isolates. We proposed that they are from other serogroups which beyond the field we can characterize.

\section{Conclusion}

We found that six O-antigen-specific genes can be used to discriminate certain serogroups. We verified this DNA-based typing approach, which based on detecting Leptospira $\mathrm{O}$-antigen-encoding genes, as a credible and convenient method for epidemiological research. To our knowledge, this work is the first to discriminate serogroups of leptospira based on the presence or absence of a PCR product.

\section{Methods}

\section{Bacterial strains and culture conditions}

The reference strains and clinical strains are listed in additional file 1 Table S1 and additional file 2 Table S2, respectively. All strains were grown in Ellinghausen McCullough Johnson Harris (EMJH) liquid medium at $28^{\circ} \mathrm{C}$ [35]. The cells were harvested at mid-log-phase by centrifugation at $12,000 \times \mathrm{g}$ for $15 \mathrm{~min}$ at $4^{\circ} \mathrm{C}$.

\section{MAT}

The MAT was performed according to the standard procedure [36] with minor modifications [37]. Live Leptospira cell suspensions (representing 18 serogroups) were added to serially diluted standard hyperimmune
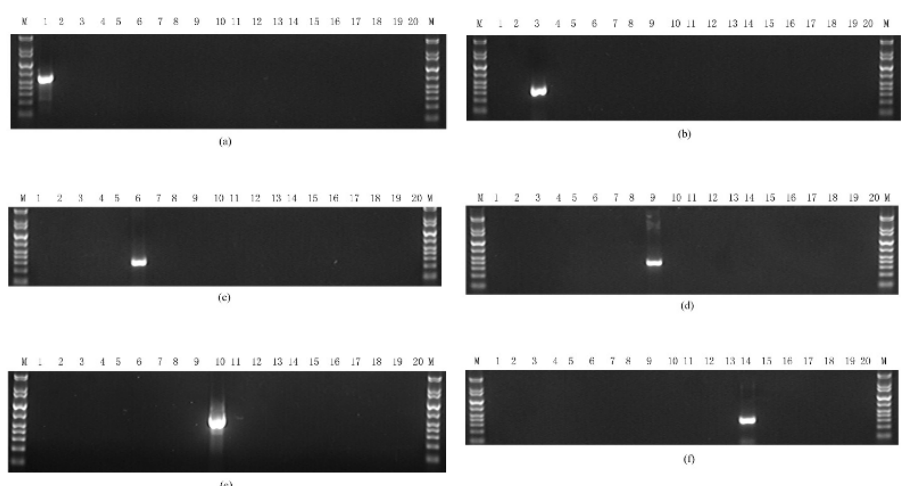

Figure 1 Analysis of amplification products by electrophoresis. Amplification products obtained by PCR of DNA pools from 18 serogroups belonging to Leptospira and DNA of two non-Leptospira strains using primer pairs ict-F/R (a), can-F/R (b), aut-F/R (c), gri-F/R (d). heb-F/R (e), sej-F/R (f). 1: Icterohaemorrhagiae; 2: Javanica; 3: Canicola; 4: Ballum; 5: Pyrogenes; 6: Autumnalis; 7: Australis; 8: Pomona; 9: Grippotyphosa; 10: Hebdomadis; 11: Bataviae; 12: Tarassovi; 13: Manhao; 14: Sejroe; 15: Mini; 16: Celledoni; 17: Ranarum; 18: Sarmin; 19: S. enteritidis H9812; 20: S. aureus N315; M: DNA marker, bands with lengths of 10 kb, 8 kb, 5 kb, 2 kb 1000 bp, 700 bp, 500 bp, 400 bp, 300 bp, 200 bp and 100 bp, respectively. 
rabbit serum (from National Institute for the Control of Pharmaceutical and Biological Products) in 6-well flatbottom microtiter plates and incubated at $37^{\circ} \mathrm{C}$ for $1 \mathrm{~h}$. Agglutination was examined by dark-field microscopy at $100 \times$ magnification. The reported titer was calculated as the reciprocal of the highest dilution of serum that agglutinated at least $50 \%$ of the cells for each serovar used. Serogroups (serovars in parentheses) included in the antigen panel were as follows: Australis (Australis), Autumnalis (Autumnalis), Ballum (Ballum), Bataviae (Bataviae), Canicola (Canicola), Celledoni (Anhoa), Grippotyphosa (Grippotyphosa), Hebdomadis (Hebdomadis), Icterohaemorrhagiae (Lai), Javanica (Javanica), Manhao (Qingshui), Mini (Mini), Pomona (Pomona), Pyrogenes (Pyrogenes), Sejroe (Wolffi), and Tarassovi (Tarassovi).

\section{DNA manipulations and bioinformatic analysis}

Genomic DNA was prepared with a bacterial DNA minikit (Watsonbiot, China) as previously described [38]. The genomic draft sequences of four strains (Gui44, Lin4, Lin6 and C401) were sequenced by 454 sequencing and the protocol was followed by Margulies's paper [39]. All related contigs found with a BLASTX alignment to known $\mathrm{O}$-antigen genes were ordered and oriented into scaffolds with the reference strains' genomes, Lai [33], JB197, L550 [40] and Fiocruz L1-130 [41]. Sanger sequencing was performed for PCR amplicons that filled the gaps between neighboring contigs. The prediction of putative coding sequences (CDSs) and gene annotation were done by GLIMMER 3 [42] and Genemark http://opal.biology.gatech.edu/GeneMark/. ORFs were assigned functions based on a comparison with the most significant homologues in the NCBI databases and are summarized in the supplemental material.

\section{Specificity test of serogroup-specific PCR assay}

The primers for the serogroup-specific PCR are listed in Table 1. PCR amplification was performed with $20 \mu \mathrm{l}$ volumes containing $10 \times \mathrm{PCR}$ buffer, $1.5 \mathrm{mM} \mathrm{MgCl}{ }_{2}$, $100 \mathrm{mM}$ deoxynucleoside triphosphates, $0.1 \mu \mathrm{M}$ of each primer, 2.5 U Taq DNA polymerase (Takara), $50 \mathrm{ng}$ template DNA and PCR-grade water. Thermal PCR conditions were as follow: initial denaturation, $95^{\circ} \mathrm{C}$ for 2 min; 30 cycles of $30 \mathrm{~s}$ at $95^{\circ} \mathrm{C}$ (denaturation), $30 \mathrm{~s}$ (annealing) at temperatures varying according to the $\mathrm{Tm}$ of the primer pair (annealing temperatures are listed in Table 1) and $1 \mathrm{~min}$ at $72^{\circ} \mathrm{C}$ (extension); final extension was at $72^{\circ} \mathrm{C}$ for $2 \mathrm{~min}$. Amplification products were analyzed by electrophoresis through a $1 \%(\mathrm{wt} / \mathrm{vol})$ agarose gel at $100 \mathrm{v}$ for $30 \mathrm{~min}$ in $0.5 \times$ TBE.

The specificity of each PCR was assessed using 75 reference strains, 40 isolates and the non-leptospira strains of S. enteritidis $\mathrm{H} 9812$ and S. aureus N315.

\section{Nucleotide sequence accession numbers}

Nucleotide sequences are available under the following accession numbers: $\mathrm{O}$-antigen gene clusters of strains Gui44, Lin4, Lin6 and C401 are FJ976886, FJ976887, FJ976888 and FJ976889, respectively.

\footnotetext{
Additional file 1: Table S1: Results of reference strains discriminated with O-genotyping. Details about 75 reference strains and

O-genotyping results are included in this table.

Click here for file

[http://www.biomedcentral.com/content/supplementary/1471-2180-1067-S1.DOC]

Additional file 2: Table S2: Results of clinical strains discriminated with O-genotyping. Details about 40 clinical strains and O-genotyping results are included in this table.

Click here for file

[http://www.biomedcentral.com/content/supplementary/1471-2180-1067-S2.DOC]

Additional file 3: Tables S3-S6. Table S3: Putative genes in the L. interrogans serogroup Canicola serovar Canicola str.gui44 O-antigne gene clusterDetails about putative genes in the L. interrogans serogroup Canicola serovar Canicola str.gui44 O-antigne gene cluster are included in this table. Table S4: Putative genes in the L. interrogans serogroup Autumnalis serovar Autumnalis str.lin4 O-antigne gene clusterDetails about putative genes in the $L$. interrogans serogroup Autumnalis serovar Autumnalis str.lin4 O-antigne gene cluster are included in this table. Table S5: Putative genes in the L. interrogans serogroup Grippotyphosa serovar Linhai str.lin6 O-antigne gene clusterDetails about putative genes in the L. interrogans serogroup Grippotyphosa serovar Linhai str.lin6 O-antigne gene cluster are included in this table. Table S6: Putative genes in the L. interrogans serogroup Hebdomadis serovar Hebdomadis str.C401 O-antigne gene cluster. Details about putative genes in the L. interrogans serogroup Hebdomadis serovar Hebdomadis str.C401 O-antigne gene cluster are included in this table.

Click here for file

[http://www.biomedcentral.com/content/supplementary/1471-2180-1067-S3.DOC]
}

\section{Acknowledgements}

This work was supported in part by the National Natural Science Foundation of China (grant numbers 30770111, 30670102, 30770820, 30970125, 30900051), the National Key Program for Infectious Diseases of China (grant numbers 2008ZX10004-002, 2008ZX10004-009, 2009ZX10004-712), the National High Technology Research and Development Program of China, and the Program of Shanghai Subject Chief Scientist (grant number 09XD1402700)

We thank Bao-Yu Hu (Department of Medical Microbiology and Parasitology, Shanghai Jiao Tong University School of Medicine), Yi-Xin Nie (National Institute for Communicable Disease Control and Prevention, Chinese Center for Disease Control and Prevention) and Ying-Chao Yang (Department of Strains, National Institute for the Control of Pharmaceutical and Biological Products) for help in bacterial culture preparation. We are thankful to HongLiang Yang for thoughtful comments on the manuscript.

\section{Author details}

'Department of Medical Microbiology and Parasitology, Institutes of Medical Sciences, Shanghai Jiao Tong University School of Medicine, Shanghai 200025, China. ${ }^{2}$ Cell Biology/Key Laboratory of Synthetic Biology, Institute of Plant Physiology and Ecology, Shanghai Institutes for Biological Sciences, Chinese Academy of Sciences, Shanghai 200032, China. ${ }^{3}$ Key Laboratory of Systems Biology, Institute of Biochemistry, Shanghai Institutes for Biological Sciences, Chinese Academy of Sciences, Shanghai 200032, China. ${ }^{4} 1$ st Bacterial Vaccine Division, National Institute for the Control of Pharmaceutical and Biological Products, Beijing 100050, China. ${ }^{5}$ National Institute for Communicable Disease Control and Prevention, Chinese Center for Disease Control and Prevention (ICDC, China CDC), PO Box 5, Changping, 
Beijing 102206, China. ${ }^{6}$ Shanghai-MOST Key Laboratory of Health and Disease Genomics, Chinese National Human Genome Center at Shanghai, Shanghai, China.

\section{Authors' contributions}

CSC and XKG designed the research project and prepared the manuscript. CSC, YZZ and ZY carried out sequencing and data analysis. XFX and XGJ performed the strains culture and MAT. XLL, PH and JHQ performed PCR assays. GPZ and SYW participated in the design of the study and helped to draft the manuscript. All authors read and approved the final manuscript.

Received: 23 September 2009 Accepted: 3 March 2010

Published: 3 March 2010

\section{References}

1. Faine S, Adler B, Bolin C, Perolat P: Leptospira and Leptospirosis. Melbourne, Australia: Medisci, 2 1999.

2. Brenner DJ, Kaufmann AF, Sulzer KR, Steigerwalt AG, Rogers FC, Weyant RS: Further determination of DNA relatedness between serogroups and serovars in the family Leptospiraceae with a proposal for Leptospira alexanderi sp. nov. and four new Leptospira genomospecies. International journal of systematic bacteriology 1999, 49(Pt 2):839-858.

3. Ramadass P, Jarvis BD, Corner RJ, Penny D, Marshall RB: Genetic characterization of pathogenic Leptospira species by DNA hybridization. International journal of systematic bacteriology 1992, 42:215-219.

4. Cerqueira GM, Picardeau M: A century of Leptospira strain typing. Infect Genet Evol 2009, 9:760-768.

5. Slack AT, Galloway RL, Symonds ML, Dohnt MF, Smythe LD: Reclassification of Leptospira meyeri serovar Perameles to Leptospira interrogans serovar Perameles through serological and molecular analysis: evidence of a need for changes to current procedures in Leptospira taxonomy. International journal of systematic and evolutionary microbiology 2009, 59:1199-1203.

6. Ko Al, Goarant C, Picardeau M: Leptospira: the dawn of the molecular genetics era for an emerging zoonotic pathogen. Nature reviews 2009, 7:736-747.

7. Kmety $\mathrm{E}$, Dikken $\mathrm{H}$ : Classification of the Species Leptospira interrogans and the History of Its Serovars. A History of the Publication of the Serovars of Leptospires, and a Catalogue of their Relationships. University Press Groningen, Groningen, the Netherlands 1993

8. Bharti AR, Nally JE, Ricaldi JN, Matthias MA, Diaz MM, Lovett MA, Levett PN, Gilman RH, Willig MR, Gotuzzo E, Vinetz JM: Leptospirosis: a zoonotic disease of global importance. The Lancet infectious diseases 2003, 3:757-771.

9. Bolin C: Leptospirosis. Emerging diseases of animals ASM Press, Washington, DCBrown C, Bolin C 2000, 185-200.

10. Levett PN: Leptospirosis. Clinical microbiology reviews 2001, 14:296-326.

11. Anonymous: Human leptospirosis:guidance for diagnosis, surveillance and control. World Health Organization, Geneva, Switzerland 2003.

12. Kalambaheti T, Bulach DM, Rajakumar K, Adler B: Genetic organization of the lipopolysaccharide O-antigen biosynthetic locus of Leptospira borgpetersenii serovar Hardjobovis. Microb Pathog 1999, 27:105-117.

13. Samuel G, Reeves P: Biosynthesis of O-antigens: genes and pathways involved in nucleotide sugar precursor synthesis and O-antigen assembly. Carbohydrate research 2003, 338:2503-2519.

14. DebRoy C, Fratamico PM, Roberts E, Davis MA, Liu Y: Development of PCR assays targeting genes in $\mathrm{O}$-antigen gene clusters for detection and identification of Escherichia coli $\mathrm{O} 45$ and $\mathrm{O} 55$ serogroups. Applied and environmental microbiology 2005, 71:4919-4924.

15. Fitzgerald C, Sherwood R, Gheesling LL, Brenner FW, Fields PI: Molecular analysis of the $\mathrm{rb} \mathrm{O}$ antigen gene cluster of Salmonella enterica serogroup 0:6,14 and development of a serogroup-specific PCR assay. Applied and environmental microbiology 2003, 69:6099-6105.

16. Tao J, Feng L, Guo H, Li Y, Wang L: The O-antigen gene cluster of Shigella boydii $\mathrm{O} 11$ and functional identification of its wzy gene. FEMS Microbiol Lett 2004, 234:125-132.

17. Bogdanovich T, Carniel E, Fukushima H, Skurnik M: Use of O-antigen gene cluster-specific PCRs for the identification and O-genotyping of Yersinia pseudotuberculosis and Yersinia pestis. J Clin Microbiol 2003, 41:5103-5112.
18. Majed Z, Bellenger E, Postic D, Pourcel C, Baranton G, Picardeau M: Identification of variable-number tandem-repeat loci in Leptospira interrogans sensu stricto. J Clin Microbiol 2005, 43:539-545.

19. Salaun L, Merien F, Gurianova S, Baranton G, Picardeau M: Application of multilocus variable-number tandem-repeat analysis for molecular typing of the agent of leptospirosis. J Clin Microbiol 2006, 44:3954-3962.

20. Zuerner RL, Alt DP: Variable nucleotide tandem-repeat analysis revealing a unique group of Leptospira interrogans serovar Pomona isolates associated with California sea lions. J Clin Microbiol 2009, 47:1202-1205.

21. Zuerner RL, Alt D, Bolin CA: IS1533-based PCR assay for identification of Leptospira interrogans sensu lato serovars. J Clin Microbiol 1995, 33:3284-3289.

22. Zuerner RL, Bolin CA: Differentiation of Leptospira interrogans isolates by IS1500 hybridization and PCR assays. J Clin Microbiol 1997, 35:2612-2617.

23. Herrmann JL, Baril C, Bellenger E, Perolat P, Baranton G, Saint Girons I: Genome conservation in isolates of Leptospira interrogans. Journal of bacteriology 1991, 173:7582-7588.

24. Herrmann JL, Bellenger E, Perolat P, Baranton G, Saint Girons I: Pulsed-field gel electrophoresis of Notl digests of leptospiral DNA: a new rapid method of serovar identification. J Clin Microbiol 1992, 30:1696-1702.

25. Perolat $P$, Lecuyer I, Postic D, Baranton G: Diversity of ribosomal DNA fingerprints of Leptospira serovars provides a database for subtyping and species assignation. Research in microbiology 1993, 144:5-15.

26. Thiermann AB, Handsaker AL, Moseley SL, Kingscote B: New method for classification of leptospiral isolates belonging to serogroup pomona by restriction endonuclease analysis: serovar kennewicki. J Clin Microbiol 1985, 21:585-587.

27. Ralph D, McClelland M, Welsh J, Baranton G, Perolat P: Leptospira species categorized by arbitrarily primed polymerase chain reaction (PCR) and by mapped restriction polymorphisms in PCR-amplified rRNA genes. Journal of bacteriology 1993, 175:973-981.

28. de la Pena-Moctezuma A, Bulach DM, Kalambaheti T, Adler B: Comparative analysis of the LPS biosynthetic loci of the genetic subtypes of serovar Hardjo: Leptospira interrogans subtype Hardjoprajitno and Leptospira borgpetersenii subtype Hardjobovis. FEMS Microbiol Lett 1999, 177:319-326.

29. de la Pena-Moctezuma A, Bulach DM, Adler B: Genetic differences among the LPS biosynthetic loci of serovars of Leptospira interrogans and Leptospira borgpetersenii. FEMS Immunol Med Microbiol 2001, 31:73-81.

30. He P, Sheng YY, Shi YZ, Jiang XG, Qin JH, Zhang ZM, Zhao GP, Guo XK: Genetic diversity among major endemic strains of Leptospira interrogans in China. BMC genomics 2007, 8:204.

31. Yan J, Dai BM, Yu ES, Qin JC, Guo XK, Jiang XG, Mao YF: Leptospirosis. People's Medical Publishing House, 3 2005, 183-186.

32. Gu JW, Jiang XG, Guo XK: Servor and Alternation of Leptospira in China. Chinese Journal of Practice Medicine 2005, 4:22-23.

33. Ren $S X, F u G$, Jiang $X G$, Zeng $R$, Miao $Y G, X u H$, Zhang $Y X$, Xiong $H, L u G$, Lu LF, Jiang HQ, Jia J, Tu YF, Jiang JX, Gu WY, Zhang YQ, Cai Z, Sheng HH, Yin HF, Zhang $Y$, Zhu GF, Wan M, Huang HL, Qian Z, Wang SY, Ma W, Yao ZJ, Shen Y, Qiang BQ, Xia QC, Guo XK, Danchin A, Saint Girons I, Somerville RL, Wen YM, Shi MH, Chen Z, Xu JG, Zhao GP: Unique physiological and pathogenic features of Leptospira interrogans revealed by whole-genome sequencing. Nature 2003, 422:888-893.

34. Wangroongsarb P, Chanket T, Gunlabun K, Long do H, Satheanmethakul P, Jetanadee S, Thaipadungpanit J, Wuthiekanun V, Peacock SJ, Blacksell SD, Smythe LD, Bulach DM, Kalambaheti T: Molecular typing of Leptospira spp. based on putative O-antigen polymerase gene (wzy), the benefit over 16S rRNA gene sequence. FEMS Microbiol Lett 2007, 271:170-179.

35. Ellinghausen HC Jr, McCullough WG: Nutrition of Leptospira Pomona and Growth of 13 Other Serotypes: Fractionation of Oleic Albumin Complex and a Medium of Bovine Albumin and Polysorbate 80. American journal of veterinary research 1965, 26:45-51.

36. Cole JR Jr, Sulzer CR, Pursell AR: Improved microtechnique for the leptospiral microscopic agglutination test. Applied microbiology 1973, 25:976-980.

37. Bajani MD, Ashford DA, Bragg SL, Woods CW, Aye T, Spiegel RA, Plikaytis BD, Perkins BA, Phelan M, Levett PN, Weyant RS: Evaluation of four commercially available rapid serologic tests for diagnosis of leptospirosis. Journal of clinical microbiology 2003, 41:803-809.

38. Qin JH, Zhang Q, Zhang ZM, Zhong Y, Yang Y, Hu BY, Zhao GP, Guo XK: Identification of a novel prophage-like gene cluster actively expressed in 
both virulent and avirulent strains of Leptospira interrogans serovar Lai. Infection and immunity 2008, 76:2411-2419.

39. Margulies M, Egholm M, Altman WE, Attiya S, Bader JS, Bemben LA, Berka J, Braverman MS, Chen YJ, Chen Z, Dewell SB, Du L, Fierro JM, Gomes XV, Godwin BC, He W, Helgesen S, Ho CH, Irzyk GP, Jando SC, Alenquer ML, Jarvie TP, Jirage KB, Kim JB, Knight JR, Lanza JR, Leamon JH, Lefkowitz SM, Lei M, Li J, Lohman KL, Lu H, Makhijani VB, McDade KE, McKenna MP, Myers EW, Nickerson E, Nobile JR, Plant R, Puc BP, Ronan MT, Roth GT, Sarkis GJ, Simons JF, Simpson JW, Srinivasan M, Tartaro KR, Tomasz A, Vogt KA, Volkmer GA, Wang SH, Wang Y, Weiner MP, Yu P, Begley RF, Rothberg JM: Genome sequencing in microfabricated high-density picolitre reactors. Nature 2005, 437:376-380.

40. Bulach DM, Zuerner RL, Wilson P, Seemann T, McGrath A, Cullen PA, Davis J, Johnson M, Kuczek E, Alt DP, Peterson-Burch B, Coppel RL, Rood JI, Davies JK, Adler B: Genome reduction in Leptospira borgpetersenii reflects limited transmission potential. Proceedings of the National Academy of Sciences of the United States of America 2006, 103:14560-14565.

41. Nascimento AL, Ko Al, Martins EA, Monteiro-Vitorello CB, Ho PL, Haake DA, Verjovski-Almeida S, Hartskeerl RA, Marques MV, Oliveira MC, Menck CF, Leite LC, Carrer H, Coutinho LL, Degrave WM, Dellagostin OA, El-Dorry H, Ferro ES, Ferro MI, Furlan LR, Gamberini M, Giglioti EA, Goes-Neto A, Goldman GH, Goldman MH, Harakava R, Jeronimo SM, Junqueira-deAzevedo IL, Kimura ET, Kuramae EE, Lemos EG, Lemos MV, Marino CL, Nunes LR, de Oliveira RC, Pereira GG, Reis MS, Schriefer A, Siqueira WJ Sommer P, Tsai SM, Simpson AJ, Ferro JA, Camargo LE, Kitajima JP, Setubal JC, Van Sluys MA: Comparative genomics of two Leptospira interrogans serovars reveals novel insights into physiology and pathogenesis. Journal of bacteriology 2004, 186:2164-2172.

42. Delcher AL, Harmon D, Kasif S, White O, Salzberg SL: Improved microbial gene identification with GLIMMER. Nucleic acids research 1999, 27:4636-4641.

doi:10.1186/1471-2180-10-67

Cite this article as: Cai et al:: Development of O-antigen gene clusterspecific PCRs for rapid typing six epidemic serogroups of Leptospira in China. BMC Microbiology 2010 10:67.

\section{Submit your next manuscript to BioMed Central and take full advantage of:}

- Convenient online submission

- Thorough peer review

- No space constraints or color figure charges

- Immediate publication on acceptance

- Inclusion in PubMed, CAS, Scopus and Google Scholar

- Research which is freely available for redistribution

Submit your manuscript at www.biomedcentral.com/submit 